\title{
After the Failed Military Coup: The Need for the Organizational Reform in the Turkish Military
}

\author{
Ramazan Erdă̆ \\ Eskişehir Osmangazi University
}

\begin{abstract}
The failed military coup of July 15, 2016, led by the Fethullah Terrorist Organization (FETO), indicates that military reform in Turkey at the operational level needs to be re-considered as an extremely urgent issue. The Justice and Development Party (AK Party) governments have made very notable structural changes in the military and have tried to control the military politically and organizationally. The need for military reform in Turkey derives from two primary reasons: the tendency of coup action and the need to improve the military's effectiveness. This article highlights the importance of reforms actualized at the strategic level during the Justice and Development Party era. It also points out the need for organizational reform in the military; reform which should be done by the civilian government in order to cope with challenges.
\end{abstract}

Keywords: Military reform, civil-military relations, AK Party, failed coup, Turkish General Staff

\section{Introduction}

Turkey shifted towards democracy in 1950 when its Democratic Party won the elections. Since then, there has been a fierce struggle between democratically elected political leaders and military cadres due to the military leaders' recurrent involvement in the politics. The first coup d'état in 1960 displayed a pro-coup structure in military against government relations. Subsequent military coups reproduced the somewhat militarist tradition ranging from military presence in society to the active involvement of military actors in politics. Essentially, the militarist tradition in Turkey was not 'produced' after the fall of the Democratic Party. It has a much longer history. One may even argue that this tradition was partially a by-product of the modernization which began in the last period of the Ottoman Empire. Yet, through consecutive military coups, the security sector, in particular the military, has strengthened its position against politicians structurally and functionally. The National Security Council (NSC) functioned as a key institution ${ }^{1}$ in making military behind-the-curtain actor-shaping security and foreign policies even during the period of elected civilian governments. This security structure changed the role of elected governments from decision-makers to decision-

Ramazan Erdă̆, Associate Professor, Department of International Relations, Eskişehir Osmangazi University. Email: ramazanerdag@hotmail.com. (1)

Ersel Aydınlı, Nihat Ali Özcan, and Doğan Akyaz, “The Turkish Military’s March Toward Europe,” Foreign Affairs 85, no. 1 (2007): 80 
practitioners. However, this traditional civil-military pattern faced a grave challenge in the early 2000s. The European Union's (EU) demands for democratization in civil-military relations coincided with the election of the Justice and Development Party (AK Party) in 2002. The AK Party not only used the EU as an anchor to transform the domestic balance between elected bodies and the military, but also followed cooperation-based foreign policy.

The AK Party government's first attempts to make changes in the foreign and domestic politics of Turkey began with accelerating the process of joining the EU. Many regulations and legislative amendments were put into effect and these changes made a positive effect in reducing the military's privileged role in politics. One of the most radical reforms was to redesign the structure and composition of the NSC to make it more of a civilly-controlled body. Amendments in 2001 and 2003 reduced the number of four-star generals in the NSC and added more ministers. These changes ensured that the decisions made by the NSC are accepted as advice rather than prioritized to government. The new composition and structure of the NSC meant that the elected governments gained an upper hand in determining Turkey's security agenda. These new regulations, which attempted to promote civilian control and make the government's role more effective at the expense of military cadres, consolidated the new structure of the NSC.

Whereas important changes were made at the strategic level of civil-military relations, Turkey witnessed a failed and bloody coup attempt on July 15, 2016. The following questions were raised by numerous individuals after the coup attempt: How was this coup attempt made despite democratic reforms, and how did many generals, officers and noncommissioned officers of FETO infiltrate the military? This article argues that satisfactory and effective changes were not materialized at the operational level in the military. Strategic level changes and transformations in civil-military relations are not alone adequate to prevent coups. The Turkish military needs both strategic and operational level changes in order to strengthen itself. This article illustrates that in addition to implementing reforms at the strategic level, reforms at an operational level are also necessary to uproot the militarist tradition and strengthen the military's operational abilities.

The article is composed of four sections. The first section examines the traditional security culture in Turkey and reviews the literature on civil-military relations. It addresses the realist security culture/tradition and the emergence of the military's historically privileged role over civil authority. The article then deals with the notable military reforms at the strategic level during the AK Party era which were in line with the EU integration process. The article explains the normalization of the military's role, in particular the NSC, within the context of the democratization of civil-military relations. The next two sections highlight that strategic level changes in military reform alone is not enough; they also debate the weakness of the current operational/organizational level changes in the military by offering options for operational level changes in legal and organizational perspectives including a new formation for the Turkish General Staff (TGS).

\section{Civil-Military Relations and Military Reform}

There is sufficient literature which verifies the need to reformulate and institutionalize civil-military relations on the principles of civil control. In this context, the importance of maintaining a forceful military with civil control has been stressed by leading experts and scholars on civil-military relations. Building a strong army to combat security threats and 
preventing the army's intervention into politics are at the center of the debate. ${ }^{2}$ The difficulty of ensuring civilian authority over military while providing a strong army has been one of the most important topics of 'security sector reform' and 'coup-proofing'. The main focal point of security sector reform has been meeting the security and democracy deficit of the armies. ${ }^{3}$ In other words, security sector reform is reformulating the role of army. ${ }^{4}$ On the other hand, as James T. Quinlivan makes clear, “'coup-proofing' [is] the set of actions a regime takes to prevent a military coup." ${ }^{.5}$ However, Pilster and Böhmelt argue that coup-proofing is not an instrumental tool in democracies. ${ }^{6}$ Regime type plays an important role in military operation ability, and armies bound by democratic principles are more effective. ${ }^{7}$ The traditional civil-military relations theory highlights the need for the separation of civilian and military institutions and civilian control over the army in order to prevent military intervention in politics. The concordance theory pays special attention to the need for interaction and cooperation among three groups of actors: the military, political elites and society. In other words, the fundamental way to prevent a possible coup is through harmonization of these three elements. ${ }^{8}$ In Turkey's case, concordance was visible among military, political elites and society from 1980 to $2002 .{ }^{9}$ But traditionally it has been difficult to create military reform in Turkey due to its security culture. ${ }^{10}$

Contrary to this traditional approach, Richard S. Wells defines civilian control over the army as a 'political process' rather than an establishment of new institutions. ${ }^{11}$ Douglas L. Bland offers a different approach and argues that the theory of shared responsibility could be successful in solving the dilemma. Bland suggests a shared understanding of responsibility between civilian authority and military elites. ${ }^{12}$ Beyond these arguments, the current literature

2 Peter D. Feaver, "The Civil-Military Problematique: Huntington, Janowitz, and the Question of Civilian Control," Armed Forces \& Society 23, no. 2 (1996): 151-52.

3 Heiner Hänggi, "Conceptualising Security Sector Reform and Reconstruction," in Reform and Reconstruction of the Security Sector in Reform and Reconstruction of the Security Sector, ed. Bryden, Alan and Heiner Hänggi (Verlag Münster: The Geneva Centre for the Democratic Control of Armed Forces-DCAF Publications, 2004), 4.

4 Timothy Edmunds, "What are Armed Forces for? The Changing Nature of Military Roles in Europe," International Affairs 82 , no. 6 (2006): 1065

5 James T. Quinlivan, “Coup-proofing: Its Practice and Consequences in the Middle East," International Security 24, no. 2 (1999): 133.

6 Ulrich Pilster and Tobias Böhmelt, "Do Democracies Engage Less in Coup Proofing? On the Relationship between Regime Type and Civil-Military Relations," Foreign Policy Analysis 8, no. 4 (2012): 355-72.

7 Ulrich Pilster and Tobias Böhmelt, "Coup-proofing and Military Effectiveness in Interstate Wars, 1967-99," Conflict Management and Peace Science 28, no. 4 (2011): 331-50; Dan Reiter and Allan C. Stam III, "Democracy and Battlefield Military Effectiveness," Journal of Conflict Resolution 42, no. 3 (1998): 259-77.

8 Rebecca L. Schiff, “Civil-Military Relations Reconsidered: A Theory of Concordance,” Armed Forces \& Society 22, no. 1 (1995): 12; Rebecca L. Schiff, “Concordance Theory: A Response to Recent Criticism,” Armed Forces \& Society 23, no. 2 (1996): $277-83$.

9 Nilüfer Narlı, "Concordance and Discordance in Turkish Civil-Military Relations, 1980-2002," Turkish Studies 12, no. 2 (2011): 215-25.

${ }^{10}$ Metin Heper, The State Tradition in Turkey (Hull: The Eothen Press, 1985); Meliha Benli Altunışı, “Turkey's Security Culture and Policy towards Iraq," Perceptions 12 (2007): 87; Ali L. Karaosmanoğlu, "The Evolution of the National Security Culture and the Military in Turkey," Journal of International Affairs 54, no. 1 (2000): 199-200; Ramazan Erdağ, "Türkiye'nin stratejik kültürü ve dış politikada yansıması [Turkey's strategic culture and reflection of foreign policy]," Akademik Incelemeler Dergisi 8, no. 1 (2013): 47-70; Murat Yeşiltaş, "The Transformation of the Geopolitical Vision in Turkish Foreign Policy," Turkish Studies 14, no. 4 (2013): 661; Narlı, "Concordance and Discordance," 216; Tuncay Kardaş, "Security Governmentality in Turkey" (PhD diss., University of Wales, Aberystwyth, 2005); Christian Rumpf, "The Military, the Presidency, and the Constitution: A Comparative Approach to the Weimar Republic, France 1958, and Turkey 1982," in State, Democracy and the Military: Turkey in the 1980s, ed. Metin Heper and Ahmet Evin (Berlin, New York: Walter de Gruyter, 1988); Ali Balc1, Dış politikada hesaplaşmak: AK parti, ordu ve Kemalizm [Confronting through foreign policy: AK party, military and Kemalism] (İstanbul: Etkileşim Yayınları, 2015); George S. Harris, "The Role of the Military in Turkey in the 1980s: Guardians or Decision-Makers?," in State, Democracy and the Military: Turkey in the 1980s, ed. Metin Heper and Ahmet Evin (Berlin, New York: Walter de Gruyter, 1988).

11 Richard S. Wells, "The Theory of Concordance in Civil/Military Relations: A Commentary," Armed Forces \& Society 23, no. 2 (1996): 272.

12 Douglas L. Bland, “A Unified Theory of Civil-Military Relations,” Armed Forces \& Society 26, no .1 (1999): 7-25. 
on civil-military relations, military reform and Turkish civil-military relations studies focus only on political decision making. This article claims that operational/organizational level reform, which strengthens the army and makes coups less likely, is also needed. In this sense, it proposes changes at the operational level for the TGS.

A conventional security/defense policy plan is composed of three levels: strategic (or political), operational (or organizational) and tactical. The strategic level, as determined by politicians, focuses on the political aims and goals of any military or defense operation. The operational level covers the planning of a specific type of operation. The tactical level is concerned with the issues and modes of operation while conducting units. The operational level "is the vital link between tactics and strategy."13 The Turkish-led Operation Euphrates Shield provides a perfect example of the interaction of the three levels: At the strategic level the decision is made to have military intervention in Syria, and the government is the decision maker. The government, of course, consults with top officials of the military and intelligence agencies, but ultimately makes the final decision alone. At the operational level these political aims (preventing terrorist attacks from northern Syria and clearing the Cerablus and al-Bab from the terrorist organization DAESH (ad-Dawlah al-Islamiyah fil-'Iraq wa ash-Sham) turn into an operation, (Operation Euphrates Shield), and the concept of military planningoperation and personnel structure is formed by military planners (TGS) in order to achieve the adopted strategic/political goals. At the tactical level all subordinate (conducting) units like the Turkish Joint Special Task Force (TJSTF) and the Free Syrian Army (FSA) try to accomplish their mission in the field under operational command.

\section{Change at the Strategic Level: Reshaping the NSC and Understanding National Security}

At the first stage, the strategic level, the harmonization and the democratic relations of the civil-military relationship is evaluated. The military, an essential organization in any country, is normally supposed to fulfill its functions under the control of a democratically-elected government. In Turkey's case, however, civil-military relations have varied over time, and the military and its highly ranked officers have been superior to governments in many periods since Turkey's establishment. Zeki Sarigil argues that from the establishment of the republic to the 1960 coup d'état (known as 'civilocracy'), the military operated under civil governments. The military coup of 1960 changed this natural relationship structure radically; it changed the roles of government and military, and the era of 'militocracy' began. The privileged role of the military continued until the 2000s. ${ }^{14}$ The EU membership process, which started at the end of the 1990s, promoted reforms in Turkey's civil-military relations. During the Europeanization period, the civil-military balance began to turn in favor of civil governments, and civilian actors/government became more effective than the military in building defense/security policy. ${ }^{15}$ After the Helsinki Summit in 1999, in which Turkey gained candidacy status to the EU, Turkey was encouraged to adopt democratic norms, in particular those concerning civil-military relations. In this sense, Turkey, in order to fulfill

${ }_{13}$ David T. Zabecki, The German 1918 Offensives: A Case Study in the Operational Level of War (Abingdon and New York: Routledge, 2006), 11.

14 Zeki Sarigil, "The Turkish Military: Principal or Agent?," Armed Forces \& Society 40, no. 1 (2014): 170-76; Tanel Demirel, "2000'li y1llarda asker ve siyaset: Kontrollü değişim ile statüko arasında Türk Ordusu [Military and politics in 2000's: Turkish Army between controlled change and status quo]," SETA Analiz 18 (2010): 8.

15 Tuba Ünlü Bilgiç, "The Military and Europeanization Reforms in Turkey," Middle Eastern Studies 45, no. 5 (2009): 803. 
the Copenhagen political criteria, started to take steps to normalize its civil-military relations at the strategic level. ${ }^{16}$ Normally, at the strategic level, the decision-making mechanism (the civil-authority government) consults with the military and attempts to benefit from this experience, but the government ultimately makes the final decisions. ${ }^{17}$ On the contrary, in Turkey the NSC became the decision-maker in national security policies, especially after the 1960 military coup. In other words, the governments governed but not ruled, and the military ruled but not governed. ${ }^{18}$ But in Turkey, in some cases, the military also governed: it provided sanitary water, education, transportation and health services in hard-to-reach rural areas.

An important security policy builder, the NSC was composed of a President, a Prime Minister, a Chief of General Staff, a Minister of State and Deputy Prime Ministers, Ministers of National Defense, Interior Affairs, Foreign Affairs, Finance, Transport and Labor and Force Commanders according to 1961 Constitution, Article No. 111, and with the Law No. 129. The 1982 Constitution, Article No.118, and Law No. 2945 changed the initial structure of the NSC after the 1980 military coup. With the 1982 regulations, the number of government members was reduced and a General Commander of the Gendarmerie was added to the NSC; thus the newly-emerged NSC included a President, a Prime Minister, a Chief of the General Staff, Ministers of National Defense, Interior Affairs, Foreign Affairs, a Commanders of Land, Sea and Air Forces and a General Commander of the Gendarmerie. This formulation strengthened the NSC's military position in the 'establishment' as compared to the 1961 Constitution. Moreover, with this change, it was accepted that the decisions of the National Security Council should primarily be made by the Prime Minister to the agenda of the cabinet. This meant that the policy-maker at the strategic (or political) level of security policy was the NSC instead of the government. The first attempts to reshape the NSC were achieved in 2001. With the amendments made in the 1982 Constitution, Article No.118, on October 17, 2001, decisions made by the NSC were now accepted as advice to government. These amendments also increased the number of civilian members in the NSC by adding Deputy Prime Ministers and a Minister of Justice.

At the beginning of the 2000s, the civil-military reform process at the strategic level accelerated during the AK Party rule. The crucial steps the AK Party made towards normalizing civil-military relations, reshaping the NSC and gaining political authority over the military have continued since the party came to power in 2002. In 2003, 2004, 2006, 2010 and 2011, following the EU Reform Packages, many changes were made in the structure of the NSC and in legal regulations. On January 18 and August 7, 2003, with the amendments made in the Law No. 2945 to harmonize with the constitutional amendment of 2001, the NSC was transformed into a national security 'advisory' body to the government. The task description of the NSC was revised and restricted. The principle of holding the meeting once every two months instead of monthly was accepted. It also opened the door to appointing a civilian secretary general to the NSC. Civilians can now been appointed to

\footnotetext{
16 Şule Toktaş and Ümit Kurt, “The Turkish Military's Autonomy, JDP Rule and the EU Reform Process in the 2000s: An Assessment of the Turkish Version of Democratic Control of Armed Forces (DECAF)," Turkish Studies 11, no. 3 (2010): 388-89; Aydınlı, Özcan, and Akyaz, "The Turkish Military's," 77-90; Metin Heper, "The European Union, and the Military and Democracy in Turkey," South European Society and Politics 10, no. 1 (2009): 33-44; Nil S. Şatana, "Civil-Military Relations in Europe, the Middle East and Turkey," Turkish Studies 12, no. 2 (2011): 279-92; Arzu Güler and Cemal Alpgiray Bölücek, "Motives for Reforms on Civil-Military Relations in Turkey," Turkish Studies 17, no. 2 (2016): 251-71.

${ }_{17}$ Tanel Demirel, "Civil-Military Relations in Turkey: Reflections on Two Notable Patterns of Civilian Behavior," Turkish Studies 4, no. 3 (2003): 2

18 Steven A. Cook, Ruling But Not Governing: The Military and Political Development in Egypt, Algeria, and Turkey (Baltimore: The John Hopkins University Press, 2007).
} 
the position of secretary general of the NSC from 2004 onward. The NSC's authorization to access public institutions was limited. In 2004, amendments were made to the Constitution in the framework of harmonization efforts with the EU. With these amendments, State Security Courts were removed and the implementation of the representation of the TGS in the Council of Higher Education $(Y \ddot{O K})$ and the nomination of the NSC to the Radio and Television Supreme Council $(R T \ddot{U} K)$ membership were terminated. The Secretary General of the NSC was removed from Communications High Board and, most importantly, military expenditures were opened to the Court of Accounts.

The Protocol on the Cooperation for Security and Public Order (EMASYA), which gave authority to the military to intervene in social events without the authorization and request of governor, dated back to 1997, but was repealed in 2010. This same year, with the acceptance of the constitutional amendment by the people on September 12, further steps towards normalization of civil and military relations were achieved. With this amendment, the Supreme Military Council's (YAŞ) decisions were opened for judicial review. Previously, military courts were tasked to try military crimes committed by military personnel and the actions taken against them for crimes against military personnel or military service and duties. It allowed civilian courts to try military personnel for crimes which defied Turkish (criminal) civilian law, including crimes against constitutional order and state security.

In 2012, the 'National Security Course', compulsory in all high schools since 1926, was removed from high school curriculums. ${ }^{19}$ Finally, a development that can be considered to be the most important stage in normalizing civil-military relations occurred in 2013. The government changed the most criticized law article, Law No. 211, Article 35, which defines military duties and is shown as the legal basis of military coups. Before this change, Article 35 recognized the military to be the guardian of the Republic against internal and external threats. ${ }^{20}$ The amended article redefined the military's duty as "to protect the Turkish homeland against threats and dangers to come from abroad, to ensure the preservation and strengthening of military power in a manner that will provide deterrence, to fulfill the duties abroad with the decision of the Parliament and help maintain international peace." ${ }^{21}$ This amendment eliminated the military's role as guardian and directed it, in particular, to be concerned with external threats to the state.

Another important aspect related to the NSC is its decisive role in forming the country's defense and security policy, the 'National Security Policy Document', also known by the popular name 'Red Book' (Milli Güvenlik Siyaset Belgesi-Kırmızı Kitap). Turkey’s national security strategy document is formed and prepared by the Secretariat of the NSC and, once approved by the NSC, becomes a national security policy for government. After approval by the NSC, no one, including parliament or other public institutions, can make any change within the document. ${ }^{22}$ The document can only be revised in years ending with zero or five. Revisions made to the document (most recently in 2015) by the AK Party governments reflect the steps that were taken at the strategic level.

19 Tim Jacoby and Alpaslan Özerdem, Peace in Turkey 2023: The Question of Human Security and Conflict Transformation (Plymouth: Lexington Books, 2013), 126.

20 Bilgiç, "The Military," 807.

21 "Turkish Parliament OKs change on coup pretext article," Hürriyet Daily News, June 14, 2013.

22 Ümit Cizre, "Demythologyzing the National Security Concept: The case of Turkey," The Middle East Journal 57, no. 2 (2003): 221 . 
It can be argued that from 1960 to 2002 the military played an important role not only in defense/security planning but also in designing domestic politics through direct and indirect intervention in political life and by redesigning political parties and leaders in Turkey. At the beginning of the 2000s, in particular under AK Party rule, Turkey made very important progress in normalizing civil-military relations. At the strategic level, the military returned the security/defense political power (which did not actually belong to it) to the government. In other words, during the AK Party era, governments began to set the security agenda while the military began to act similarly to those in other democratic countries; that is, the government both ruled and governed.

\section{The Failed Coup and Re-organization of the Military Architecture}

On one hand, the AK Party governments made radical and brave changes to strategic-level reform in civil-military relations, incomparable even to former periods; on the other hand, Turkey witnessed a failed but bloody military coup attempt led by FETO on July 15, 2016. Studies on civil-military relations and the power of the military in Turkish politics have predominantly focused on the NSC's role and the attempts made to reformulate it. After the adaptation of EU norms and the changes at the strategic level of the national security policy architecture, in particular the reformulation of the NSC, it was argued that the military coup era had come to an end. Nevertheless, the failed military coup shows that this argument was not accurate.

Nonetheless, the failed military coup was different from past experiences in many ways. First, it was carried out by a terrorist organization made up of civilian and military members. Second, it was directed by parties outside of the military; in particular by FETO's civilian members. And third, it was repelled by the public. After the failed military coup, the government took rapid steps toward reforming the military. Many generals, officers and noncommissioned officers who were involved in the coup were purged from the army. Military high schools, colleges and academies were closed and all military colleges and academies were re-opened under the new establishment of the National Defense University. Military hospitals, their personnel and equipment were transferred to the Ministry of Health. The composition and member structure of the YAŞ was modified and a number of military members were replaced by government members. In the first YAŞ meeting after the failed coup, for the first time in history, many non-staff colonels became generals. It was now possible for the President and the Prime Minister to receive information and give orders to the military under the force commanders. All force commanders, as well as the administration of shipyards, factories, and industrial establishments that had been under control of the military, were assigned to the Ministry of National Defense (MOD). Gendarmerie and Coast Guard Command were directly assigned to the Ministry of Internal Affairs. ${ }^{23}$ Even though some changes were made at the operational level in the military after the failed coup, a comprehensive approach is still needed and special attention should be paid to the military's transformation at this level.

\subsection{At the operational level: Reform of the General Staff}

Current debates on military reform at the operational (or organizational) level in Turkey roughly revolve around two basic patterns: The integration of the TGS to the MOD, and the

${ }^{23}$ Deniz Zeyrek, "TSK sil baştan [TAF de novo] ," Hürriyet, July, 31, 2016, accessed May 20, 2017, .com.tr/tsk-silbastan-40177172. 
replacement of compulsory military service with professional service. ${ }^{24}$ Apart from these two arguments, reform and reformulation of the TGS have not been thoroughly discussed and it is 'typically' seen as a sphere devoted to military. Military reform at the operational level requires change that goes beyond these arguments and should be dealt with by government. The AK Party government, during their 15-year rule, gradually carried out critical changes at the strategic level on national security issues, and rearranged civil-military relations which then enabled government to conduct final decisions. However, it's hard to say that these adaptations were seen at the organizational level until the failed coup. There are two important challenges at this stage in reforming the TGS: 'exceptionalism' and 'dysfunction'.

At the operational level, one of the most important initiatives was "The Defense Reform Report”, prepared by an expert group (Head of the Working Group was undertaken by Prof. Ali Karaosmanoğlu) and initiated by Turkey's Presidency in 2013. The report begins with a comprehensive analysis of global and regional transformation since the end of the Cold War. After briefing the civil-military transformation after the end of the Cold War, the report also deals with TAF's duties and necessary capabilities. The report makes a comparative analysis of Turkey's defense management, defense system supply and logistics, defense expenses and supervision of the defense budget among allies and developed countries. The report suggests enhancing professional military service, upgrading the training levels of officers and noncommissioned officers, keeping defense spending at least in the world average and increasing the number of experts in the Court of Accounts, especially in defense expenditures. ${ }^{25}$ Although the report offers practical suggestions (such as the gradual removal of compulsory military service), the acts of transferring the exterior security of the prisons to the Ministry of Justice and the land borders' security to the Ministry of Interior have not been deeply discussed.

The report draws attention to the need for an air defense system, a combined rapid reaction force similar in structure to NATO's Rapid Reaction Force (NRF), due to the risks and security threats that Turkey faces. In terms of TGS and MOD relations, the report presents two approaches: The first argues that defense management should be conducted by the TGS, and missions aside from military duties should be carried out by MOD. The second approach suggests that the current relationship between the TGS and the MOD should not be changed in the short term within Western examples and for EU process reasons. ${ }^{26}$ In other words, the report considers the TGS as a player at the strategic level. This article goes beyond this argument and proposes that the TGS should be a player at the operational level, and the strategic level should be left to politics.

Many security reform studies and constitutional-legal amendments have ignored the restructuring of the TGS. For instance, the death penalty has been abolished in criminal law but in Military Criminal Law, No. 1632 article 20, the death penalty still exists. In another case, the Ombudsman Institution was established in 2012 but only 'the military activities' of the TAF are excluded from the scope of that institution. Actually, the Ombudsman Instuition

${ }^{24}$ Levent Ünsald1, Türkiye'de asker ve siyaset [Military and politics in Turkey], trans. Orçun Türkay (İstanbul: Kitap Yayınevi, 2008), 144-77; İsmet Akça, Türkiye'de askeri-iktisadi yapı: Durum, sorunlar, çözümler [Military-economic structure in Turkey: Situation, problems, solutions] (İstanbul: TESEV Publications, 2010).

${ }_{25}$ Presidency of the Republic of Turkey, "Savunma reformu raporu" [Defense reform report], 2014, accessed November 20, 2017, https://www.memurlar.net/common/news/documents/602402/2014-08-22-savunmareformu.pdf.

26 "Outgoing President Gül urges gov't to allow Parliament scrutiny over defense expenditure," Hürriyet Daily News, August 22, 2014, accessed July 14, 2017, http://www.hurriyetdailynews.com/outgoing-president-gul-urges-govt-to-allow-parliamentscrutiny-over-defense-expenditure-.aspx?pageID=238\&nid=70787. 
is also essential for military's activities. Similarly the TGS is dismissed in the scope of the Ethics Board of Public Officers.

The need for reform of the TGS at the operational level emerges from two aspects: First, even in 2016 it appeared to be a (albeit limited) coup-generating mechanism in the military, although large segments of the military did not participate in the coup attempt. Second, the military's operational ability needs to be strengthened against external threats. Of course " $\mathrm{t}]$ o change institutions and the way of thinking proves to be a daunting task." ${ }^{27}$ Reform at an organizational level should begin with the institutional name. The traditional name of the military in Turkey is TAF, yet at no point is 'TAF' among the official institutions that are named in the general budget. Although its official website uses the acronym TAF (www. tsk.tr/HomeEng), the official name is 'General Staff'. Furthermore, many laws and legal regulations involving the military begin with $\mathrm{TAF}^{28}$ In order to harmonize the common usage of the intuitional name, the article offers to rename the military the 'Turkish Armed Forces Command' (TAFC). This change could remove the complexity of the name and strengthen the Chief of General Staff's operational command by making it the 'TAF Commander' to all subordinate units of the military (Land, Navy, Sea and Special Forces) rather than chief. The current position of the Chief of General Staff resembles a strategic coordination authority between civilian authority (government) and military, rather than an operational commander.

A second policy change relates to organizational structure. Currently the TGS is likely composed of four Chiefs of General Staff, and they each have independent headquarters and directories (Land, Navy, Sea and Special Forces). In order to reinforce the command and operational capacity of the military, the TGS needs to unify all headquarters (Land, Sea, Air and Special Forces) as 'a joint force' under the TAFC. The TAF Commander (replacing the Chief of General Staff) would create plans for, command and directly control the four forces. This name suggests that within a unique and joint headquarter structure, the TAF Commander's could be assured full command and control over all activities of the Land, Navy, Sea and Special Forces directories. With this change, the four Deputy Commanders of TAFC should be responsible for Land, Navy, Sea and Special Forces, instead being the force commanders. This could prevent the risk of coup by subordinate units of the military independent from the General Staff. A successful example on a micro-level of this security architecture has been applied in the Operation Euphrates Shield as the Turkish Joint Special Task Force.

Third, according to Article 7 of the Law No. 1324 on the Duties and Authorizations of the Chief of the General Staff, the Chief of General Staff is "responsible to the Prime Minister for his duties and authorities". As understood from the text of law, this responsibility is defined as belonging personally to the Chief of General Staff. Although the Chief of General Staff is described as the "Commander of the Armed Forces in Peace and War" in Article 1 of the same law, and this responsibility should be institutionally understood, no organic link has been established between the Chief of Staff and the state organization. In order to fill this gap, institutional reform debates have focused on attaching the TGS to the MOD.

As Tanel Demirel rightfully argues, without transforming the MOD into a defense and national security institution, putting the TGS under the control of the MOD may not

${ }_{27}$ Peter M. E. Volten, "Transatlantic Security, Defence and Strategy: Badly Needed Reforms," All Azimuth 4, no. 1 (2015): 54.

${ }_{28}$ For example, Turkish Armed Forces Internal Service Law No. 211, Turkish Armed Forces Disciplinary Law No. 6413, Turkish Armed Forces Supply Law No. 5668, Turkish Armed Forces Personnel Mobilization Regulation etc. 
be functional. ${ }^{29}$ The MOD, with its current structure, is a long way from being a national security institution. If the TGS was to be attached to the MOD, the Turkish MOD could be strengthened both in terms of its physical conditions and its civilian personnel (exemplified in the US MOD, the Pentagon). The functional role of the ministry is to supply the current needs of the military and conduct military procurement. By accepting the constitutional change of April 16, 2017, it might be presumed that the TGS will be put directly under control of Turkey's Presidency as a National Intelligence Service. In terms of a second operational reform debate, abolishing compulsory military service and replacing professional soldiers reflects down-top professionalism. To be sure, professional soldiers may conduct more active and effective combat. As Samuel Huntington stressed, "[t]he military profession is expert", so military personnel training should focus on military duties and operational troops should be composed of well-trained and well-equipped personnel.

During the Cold War, militaries were composed of units that were conventional and large in number. But force structures of militaries have changed since the end of the Cold War. In the case of land forces, many countries have minimized land force units and changed the force structure from division-regiment to brigade-battalion. Turkey has followed this path and minimized divisions to brigades, and regiments to battalions, in order to enhance maneuver capability. But the number of the ranks of major generals (two stars) and colonels has remained the same as in the division-regiment establishment. In order to balance the rank architecture and to rejuvenate the age of being a general, one might consider removing the ranks 'colonel' and 'major general', or reducing the waiting period for promotion in these ranks. Another aspect of the personnel structure of the military is that there are no normative regulations or norms for promotions. Although the structure and composition of the High Military Council (YAŞ) was changed after the failed military coup on July 15, 2016, the lack of criteria for promotion, in particular for moving from colonel to general, ${ }^{31}$ provided fertile ground for FETO members to infiltrate the military's top ranks. All the colonels evaluated in YAŞ are potential candidates for becoming a general, and the one who is able to get the most votes from its members is promoted. In this instance, customs were taken into account for the promotions, and FETO members' officers who seemed to be the most faithful to the system were promoted.

With the constitutional amendments in 2010, the way to judge YAŞ decisions was opened but the promotion process and retirement due were excluded ${ }^{32}$ and remained closed. In the text which was first presented to the Parliamentary Constitutional Commission, the way to judge all YAŞ decisions would be opened, but the promotion process and retirement due to cadres was excluded in the Commission. With the constitutional change that was accepted in April 16, 2017, the way to judge YAŞ decisions on the promotion process and retirement due to cadres can be opened. ${ }^{33}$

Another point that needs special attention is the force deployment of the military. When

29 Demirel, "2000'li yıllarda [in 2000's]," 25.

${ }^{30}$ Samuel P. Huntington, The Soldier and the State: The Theory and Politics of Civil-military Relations (Cambridge and London: The Belknap Press of Harvard University Press, 1957), 70.

${ }^{31}$ The terms of general has two meaning in military terminology. One of the meaning refers to general status (cover all general one, two, three and four stars) the other refers to highest general rank four stars general only.

32 Oya Armutçu and Bülent Sarıŏlu, "YAŞ'ın terfi ve emeklilik işlemleri yargı denetimi dışı [YAŞ’s promotion and retirement procedures are not subject to judicial review]," Hürriyet, March, 20, 2011, accessed May 10, 2017, http://www.hurriyet.com.tr/yasin-terfi-ve-emeklilik-islemleri-yargi-denetimi-disi-17321142. 19.

${ }_{33}$ Cem Duran Uzun, "Cumhurbaşkanlığı sisteminde yargı [The judiciary in the Presidential system]," SETA Analiz 192 (2017): 
military coups in Turkey are examined from past to present, the country-wide deployment of military has been designed to suppress the people during military coups instead of countering regional threats. After the failed coup, the government moved armored troops from centers like Mamak and Etimesgut in Ankara to other cities in Turkey. Military elites were able decide the location of military bases and had the control to change them. In this sense, the locations of military bases should be re-evaluated due to regional and global security risks and threats.

Many reform proposals of civil-military relations focus on controlling the military through civilian actors, namely governments. In order to prevent coups and ensure coupproofing, these proposals, suggestions and reforms address the military's intervention in politics. Studies on civil-military relations attracted the attention of international-relations scholars within the recent coups of many countries. Theory of civil-military relations has stressed the need for the separation of the military from the political arena. Strategic-level reform studies of civil-military relations have emphasized the strength of the army on one hand, and preventing the military's engagement in politics on the other. Turkey has made important reforms at the strategic level, especially in the EU accession process. Recent reforms in Turkey and other countries at the strategic level have served them well in terms of providing civil control over militaries. For example, the NSC, the institution over which the military elite is most influential in Turkish politics, was restructured during the course of reform studies by making sure that political actors are more numerous and more effective in the decision-making process. But the coup attempt led by FETO on July 15, 2016 has shown the need for reforms at the operational level. In short, this article suggests the need for military reform at the operational level in Turkey.

\section{Conclusion}

Turkey has been undergoing significant changes and transformations under the AK Party rule since 2002. Two of the reform agendas of the AK Party are improving civil-military relations and re-organizing the military. As a motivating and constitutive factor, Turkey's membership in the EU has made these reforms necessary; the AK Party government has accelerated the reform process of civil-military relations that began before its rule. Notable changes at the strategic level were achieved with the EU reform packages and the government has normalized institutional relations with the military. The democratic consolidation of the government over the military has strengthened the government's role in setting national security policies and security agenda. However, reform at the operational (organizational) level in the military was not considered to be a priority and has been left in the responsibility of the military.

This article points out the military reforms that have occurred at the strategic level, and goes on to propose organizational changes at the operational level. It also proposes a new composition of the TGS as TAFC with a new joint-force structure. The main goal of this proposal is to empower the military and prevent it from intervening in politics by leaving decisions at the strategic level to politicians. 


\section{Bibliography}

Akça, İsmet. Türkiye'de askeri-iktisadi yapı: Durum, sorunlar, çözümler [Military-economic structure in Turkey: Situation, problems, solutions]. İstanbul: TESEV Publications, 2010.

Altunışık, Meliha Benli. “Turkey’s Security Culture and Policy towards Iraq.” Perceptions 12 (2007): 69-88.

Armutçu, Oya, and Bülent Sarığlu. "YAŞ’ın terfi ve emeklilik işlemleri yargı denetimi dışı [YAŞ’s promotion and retirement procedures are not subject to judicial review]." Hürriyet, March, 20, 2011. Accessed May 10, 2017. http://www.hurriyet.com.tr/yas-in-terfi-ve-emeklilik-islemleri-yargi-denetimi-disi-17321142.

Aydınl, Ersel, Nihat Ali Özcan, and Doğan Akyaz. “The Turkish Military’s March Toward Europe.” Foreign Affairs 85, no. 1 (2007): 77-90.

Balcı, Ali. Dış politikada hesaplaşmak: Ak parti, ordu ve Kemalizm [Confronting through foreign policy: AK party, military and Kemalism]. İstanbul: Etkileşim Yayınları, 2015.

Bilgiç, Tuba Ünlü. “The Military and Europeanization Reforms in Turkey.” Middle Eastern Studies 45, no. 5 (2009): 803-24.

Bland, Douglas L. "A Unified Theory of Civil-Military Relations.” Armed Forces \& Society 26, no. 1 (1999): 7-25.

Cizre, Ümit. "Demythologyzing the National Security Concept: The Case of Turkey." The Middle East Journal 57, no. 2 (2003): 213-29.

Cook, Steven A. Ruling but Not Governing: The Military and Political Development in Egypt, Algeria, and Turkey. Baltimore: The John Hopkins University Press, 2007.

Demirel, Tanel. "2000'li Yıllarda asker ve siyaset: Kontrollü değişim ile statüko arasında Türk Ordusu [Military and politics in 2000's: Turkish Army between controlled change and status quo]." SETA Analiz 18 (2010): 1-28.

. "Civil-Military Relations in Turkey: Reflections on Two Notable Patterns of Civilian Behavior." Turkish Studies 4, no. 3 (2003): 1-25.

Edmunds, Timothy. "What are Armed Forces for? The Changing Nature of Military Roles in Europe." International Affairs 82, no. 6 (2006): 1059-75.

Erdağ, Ramazan. “Türkiye'nin stratejik kültürü ve dış politikada yansıması [Turkey's strategic culture and reflection of foreign policy].” Akademik Incelemeler Dergisi 8, no. 1 (2013): 47-70.

Feaver, Peter D. "The Civil-Military Problematique: Huntington, Janowitz, and the Question of Civilian Control." Armed Forces \& Society 23, no. 2 (1996): 149-78.

Hänggi, Heiner. "Conceptualising Security Sector Reform and Reconstruction." In Reform and Reconstruction of the Security Sector in Reform and Reconstruction of the Security Sector, edited by Bryden, Alan and Heiner Hänggi, 1-11. Verlag Münster: The Geneva Centre for the Democratic Control of Armed Forces-DCAF Publications, 2004.

Harris, George S. "The Role of the Military in Turkey in the 1980s: Guardians or Decision-Makers?” In State, Democracy and the Military: Turkey in the 1980s, edited by Metin Heper and Ahmet Evin, 177-200. Berlin, New York: Walter de Gruyter, 1988.

Heper, Metin. "The European Union, and the Military and Democracy in Turkey." South European Society and Politics 10, no. 1 (2009): 33-44.

- The State Tradition in Turkey. Hull: The Eothen Press, 1985.

Huntington, Samuel P. The Soldier and the State: The Theory and Politics of Civil-military Relations. Cambridge and London: The Belknap Press of Harvard University Press, 1957.

Güler, Arzu, and Cemal Alpgiray Bölücek. "Motives for Reforms on Civil-Military Relations in Turkey.” Turkish Studies 17, no. 2 (2016): 251-71.

Jacoby, Tim, and Alpaslan Özerdem. Peace in Turkey 2023: The Question of Human Security and Conflict Transformation. Plymouth: Lexington Books, 2013.

Karaosmanoğlu, Ali L. "The Evolution of the National Security Culture and the Military in Turkey." Journal of International Affairs 54, no. 1 (2000): 199-216. 
Kardaş, Tuncay. "Security Governmentality in Turkey.” PhD diss., University of Wales, Aberystwyth, 2005.

Narl1, Nilüfer. "Concordance and Discordance in Turkish Civil-Military Relations, 1980-2002." Turkish Studies 12, no. 2 (2011): 215-25.

Pilster, Ulrich, and Tobias Böhmelt. "Coup-proofing and Military Effectiveness in Interstate Wars, 1967-99." Conflict Management and Peace Science 28, no. 4 (2011): 331-50.

Pilster, Ulrich, and Tobias Böhmelt. "Do Democracies Engage Less in Coup $\square$ Proofing? On the Relationship between Regime Type and Civil-Military Relations.” Foreign Policy Analysis 8, no. 4 (2012): 355-72.

Presidency of the Republic of Turkey. "Savunma reformu raporu" [Defense reform report], 2014. Accessed November 20, 2017. https://www.memurlar.net/common/news/ documents/602402/2014-08-22-savunmareformu.pdf.

Quinlivan, James T. “Coup-proofing: Its Practice and Consequences in the Middle East.” International Security 24, no. 2 (1999): 131-65.

Reiter, Dan, and Allan C. Stam III. "Democracy and Battlefield Military Effectiveness." Journal of Conflict Resolution 42, no. 3 (1998): 259-77.

Rumpf, Christian. "The Military, the Presidency, and the Constitution: A Comparative Approach to the Weimar Republic, France 1958, and Turkey 1982.” In Heper and Evin, State, Democracy and the Military, 215-38.

Sarigil, Zeki. “The Turkish Military: Principal or Agent?” Armed Forces \& Society 40, no. 1 (2014): 168-90.

Schiff, Rebecca L. "Civil-Military Relations Reconsidered: A Theory of Concordance.” Armed Forces \& Society 22, no. 1 (1995): 7-24.

. "Concordance Theory: A Response to Recent Criticism." Armed Forces \& Society 23, no. 2 (1996): 277-83.

Şatana, Nil S. "Civil-Military Relations in Europe, the Middle East and Turkey.” Turkish Studies 12, no. 2 (2011): 279- 92 .

Toktaş, Şule, and Ümit Kurt. “The Turkish Military’s Autonomy, JDP Rule and the EU Reform Process in the 2000s: An Assessment of the Turkish Version of Democratic Control of Armed Forces (DECAF)." Turkish Studies 11, no. 3 (2010): 387-403.

Uzun, Cem Duran. "Cumhurbaşkanlığı sisteminde yarg1 [The judiciary in the Presidential system]." SETA Analiz 192 (2017): 1-20.

Ünsald1, Levent. Türkiye'de asker ve siyaset [Military and politics in Turkey]. Translated by Orçun Türkay. İstanbul: Kitap Yayınevi, 2008.

Volten, Peter M. E. "Transatlantic Security, Defence and Strategy: Badly Needed Reforms.” All Azimuth 4, no. 1 (2015): 51-8.

Wells, Richard S. "The Theory of Concordance in Civil/Military Relations: A Commentary." Armed Forces \& Society 23, no. 2 (1996): 269-75.

Yeşiltaş, Murat. "The Transformation of the Geopolitical Vision in Turkish Foreign Policy.” Turkish Studies 14, no. 4 (2013): 661-87.

Zabecki, David T. The German 1918 Offensives: A Case Study in the Operational Level of War. Abingdon and New York: Routledge, 2006.

Zeyrek, Deniz. "TSK sil baştan [TAF de novo].” Hürriyet, July, 31, 2016. Accessed May 20, 2017. http://www. hurriyet.com.tr/tsk-sil-bastan-40177172. 